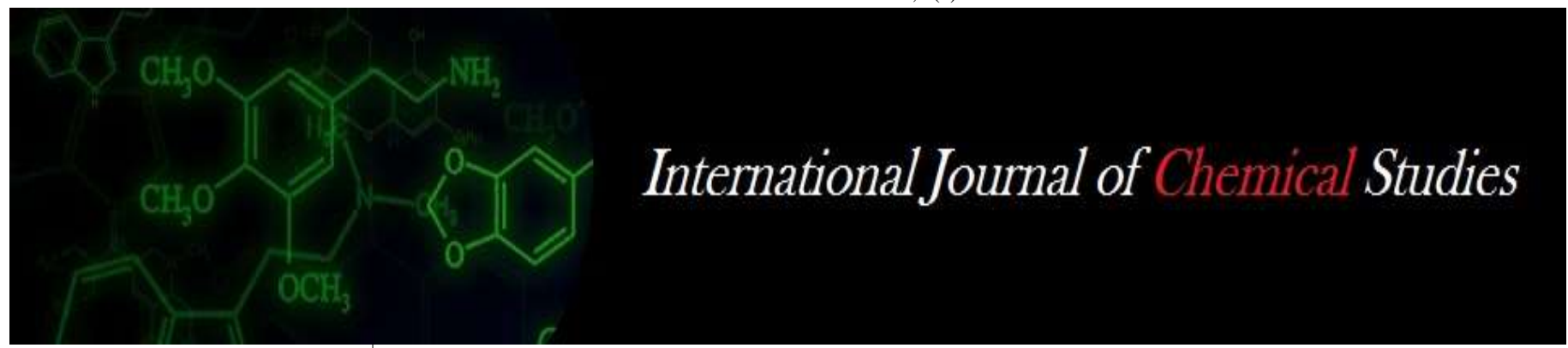

P-ISSN: 2349-8528

E-ISSN: 2321-4902

www.chemijournal.com

IJCS 2020; 8(6): 2785-2789

(C) 2020 IJCS

Received: 26-08-2020

Accepted: 06-10-2020

N Amrutha Pavani

College of Horticulture, Dr.

YSRHU, Anantharajupeta,

Y.S.R, Andhra Pradesh, India

M Raja Naik

College of Horticulture, Dr.

YSRHU, Anantharajupeta,

Y.S.R, Andhra Pradesh, India

R Nagaraju

College of Horticulture, Dr.

YSRHU, Anantharajupeta,

Y.S.R, Andhra Pradesh, India

G Srinivasa Rao

College of Horticulture, Dr.

YSRHU, Anantharajupeta,

Y.S.R, Andhra Pradesh, India

VV Padmaja

College of Horticulture, Dr.

YSRHU, Anantharajupeta,

Y.S.R, Andhra Pradesh, India

B Srinivasulu

College of Horticulture, Dr.

YSRHU, Anantharajupeta,

Y.S.R, Andhra Pradesh, India

Corresponding Author:

N Amrutha Pavani

College of Horticulture, Dr.

YSRHU, Anantharajupeta,

Y.S.R, Andhra Pradesh, India

\section{Response of ornamental plants, study sites and their interaction to various pollutants in respect of secondary metabolites, enzymes and proline content}

\author{
N Amrutha Pavani, M Raja Naik, R Nagaraju, G Srinivasa Rao, VV \\ Padmaja and B Srinivasulu
}

DOI: https://doi.org/10.22271/chemi.2020.v8.i6an.11202

\begin{abstract}
The present investigation was carried out during the year 2020 at four study sites. Corresponding to biochemical traits, peroxidase activity recorded was maximum in OP-13 (87.99 $\left.\Delta \mathrm{OD} \min ^{-1} \mathrm{~g}^{-1} \mathrm{FW}\right)$

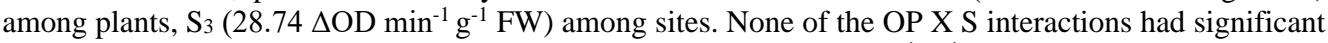
effect on this trait. Highest catalase activity of $63.48 \mu \mathrm{mol} \mathrm{H}_{2} \mathrm{O}_{2} \mathrm{~min}^{-1} \mathrm{~g}^{-1} \mathrm{FW}$ was observed in OP-15 among plants, $\mathrm{S}_{3}\left(27.98 \mu \mathrm{mol} \mathrm{H}_{2} \mathrm{O}_{2} \mathrm{~min}^{-1} \mathrm{~g}^{-1} \mathrm{FW}\right)$ among sites. This attribute had no significant influence among interaction treatments. OP-4 had maximum phenol content of $25.34 \mathrm{mg} 100 \mathrm{~g}^{-1}$ among plants, $\mathrm{S}_{3}$ $\left(6.87 \mathrm{mg}^{\left.100 \mathrm{~g}^{-1}\right)}\right.$ among sites and OP-4 X S $3\left(26.08 \mathrm{mg} 100 \mathrm{~g}^{-1}\right)$ in interactins. Flavonoid content observed to be higher in OP-4 (1.86 mg $\left.100 \mathrm{~g}^{-1}\right)$ among plants, $\mathrm{S}_{3}\left(1.47 \mathrm{mg} 100 \mathrm{~g}^{-1}\right)$ among sites and OP$1 \mathrm{X} \mathrm{S}_{3}\left(2.50 \mathrm{mg} 100 \mathrm{~g}^{-1}\right)$ among interaction combinations. Significantly higher proline content was recorded in OP-3 (158.76 $\left.\mu \mathrm{g} \mathrm{g}^{-1}\right)$ among plants, $\mathrm{S}_{3}\left(37.94 \mu \mathrm{g} \mathrm{g}^{-1}\right)$ among areas and OP-3 X S $3(183.00 \mu \mathrm{g}$ $\left.\mathrm{g}^{-1}\right)$ among interactions. Malondialdehyde content recorded was highest in OP-15 (3.66 nmol MDA g-1) among species, $\mathrm{S}_{3}\left(2.02 \mathrm{nmol} \mathrm{MDA} \mathrm{g}^{-1}\right)$ among sites. OP X S combinations showed non significant influence on MDA content.
\end{abstract}

Keywords: Horticultural ornamental plants, physiological and biochemical attributes, sites, various pollutants and landscaping

\section{Introduction}

Avenue trees, ornamental plants and shrubs are capable of removing a significant amount of air pollutants from the atmosphere and hence should be considered an integral part of any sustainable plan intended at improving air quality. Different plant species vary considerably in their susceptibility to air pollutants. Screening of plants for their sensitivity to air pollutants is of vital importance ${ }^{[1]}$. Increased urbanization, industrialization, mining and heavy vehicular traffic have resulted in deterioration of air quality has been a major problem from Mangampeta (rural site) to Tirupati (urban area) was the major problem since decades in Andhra Pradesh. Mangampeta (rural) in YSR Kadapa district of Andhra Pradesh is known for the emission of dust particles and different pollutants. Whereas Tirupati (urban) is well known for heavy vehicular movement and air pollution level is high and hence to find out the efficacy of available existing plant species in trapping the pollutants and dust particle delivered, the present investigation is planned.

Therefore, the aim of the present study is to determine the variation in attributes to establish the susceptibility level of different ornamental plants with reference to their tolerance and performance index which might be very useful in the selection of appropriate species which can be expected to perform well for the development of green environment and for landscaping. A very meagre or no work has been done on the development of landscaping with appropriate ornamental plants in Rayalaseema region of Andhra Pradesh particularly in above mentioned areas. Hence the present investigation was designed and planned by taking above constraints into consideration to find out the pollution tolerance level of various ornamental plants at multiple study sites to select appropriate plants which can be grown and expected to perform well for the development of greener environment along with landscaping purpose for a long way ahead. 


\section{Material and Methods}

The present investigation was carried out during the year 2020 at four locations viz., College of Horticulture, Anantharajupeta (Control site), Mangampeta (Barytes mining area), Rly. Kodur (Town) and Tirupati (City), Andhra Pradesh.

\section{Plant material}

Already growing, existing and commonly occurring multiple ornamental plants at four study sites were selected for investigation. College of Horticulture, Anantharajupeta (Control site- $\mathrm{S}_{1}$ ), Mangampeta (Barytes mining area and road traffic area- $\mathrm{S}_{2}$ ), Railway Kodur (Town - main road traffic area- $\mathrm{S}_{3}$ ) and Tirupati (City - main road heavy traffic area- $\mathrm{S}_{4}$ ) were selected as study sites. Three plants were selected in each treatment (ornamental plant) at random and labeled properly for recording observations. Total number of plants used was 24, with three replications and two way ANOVA was used for the analysis. In all four study sites, same ornamental plant species were selected uniformly and tagged randomly as per replication and details of plant species selected are given below.

Table 1: Treatment (ornamental plants) details

\begin{tabular}{|c|c|c|}
\hline S. No & Botanical name & Notation \\
\hline 1 & Azadirachta indica & OP-1 \\
\hline 2 & Bauhinia purpurea & OP-2 \\
\hline 3 & Delonix regia & OP-3 \\
\hline 4 & Peltophorum pterocarpum & OP-4 \\
\hline 5 & Polyalthia longifolia & OP-5 \\
\hline 6 & Ficus benjamina & OP-6 \\
\hline 7 & Conocarpus erectus & OP-7 \\
\hline 8 & Pongamia pinnata & OP-8 \\
\hline 9 & Nerium oleander & OP-9 \\
\hline 10 & Acalypha hispida & OP-10 \\
\hline 11 & Duranta repens & OP-11 \\
\hline 12 & Tabernaemontana divaricata & OP-12 \\
\hline 13 & Hibiscus rosa-sinensis & OP-13 \\
\hline 14 & Pandanus sanderi & OP-14 \\
\hline 15 & Tecoma stans & OP-15 \\
\hline 16 & Bougainvillea glabra & OP-16 \\
\hline 17 & Dieffenbachia amoena & OP-17 \\
\hline 18 & Sansevieria trifasciata & OP-18 \\
\hline 19 & Furcraea foetida & OP-19 \\
\hline 20 & Roystonea regia & OP-20 \\
\hline 21 & Wodyetia bifurcata & OP-21 \\
\hline 22 & Cycus cercinalis & OP-22 \\
\hline 23 & Catharanthus roseus & OP-23 \\
\hline 24 & Polianthes tuberosa & OP-24 \\
\hline
\end{tabular}

Note: OP-Ornamental plant

To assess the impact of air, vehicular pollution and dust particles from road sides and from control site were collected from fully matured leaves during morning hours ${ }^{[2]}$. The leaf samples were collected in polythene covers and were carried to the laboratory for analysis in the ice box. Leaves facing the roadside were plucked mainly during the peak days at a height of $1.5 \mathrm{~m}^{[3-4]}$. The data on flavonoid content ${ }^{[5]}$, phenol content ${ }^{[6]}$, proline ${ }^{[7]}$, peroxidase activity ${ }^{[8]}$, catalase activity ${ }^{[9]}$ and malondialdehyde content ${ }^{[10]}$ were recorded as per standard procedures.

\section{Results and Discussion Flavonoid content}

The flavonoid content of the ornamental plants differed significantly among different sites and interaction combinations. Among the ornamental plants, highest flavonoid content $\left(1.86 \mathrm{mg} 100 \mathrm{~g}^{-1}\right)$ was recorded in OP-1 which was on par with OP-4 (1.83 mg $\left.100 \mathrm{~g}^{-1}\right)$ and OP-20 $\left(1.83 \mathrm{mg} 100 \mathrm{~g}^{-1}\right)$. Among sites, maximum flavonoid content $\left(1.47 \mathrm{mg} 100 \mathrm{~g}^{-1}\right)$ was recorded at $\mathrm{S}_{3}$ followed by $\mathrm{S}_{2}(1.13 \mathrm{mg}$ $\left.100 \mathrm{~g}^{-1}\right), \mathrm{S}_{4}\left(0.77 \mathrm{mg} 100 \mathrm{~g}^{-1}\right)$. In interaction of ornamental plants and sites, the combination of OP-1 $\mathrm{X}_{3} \mathrm{~S}_{3}$ gave maximum value $\left(2.50 \mathrm{mg} 100 \mathrm{~g}^{-1}\right)$ which was on par with OP$16 \mathrm{X} \mathrm{S}_{3}\left(2.48{\left.\mathrm{mg} 100 \mathrm{~g}^{-1}\right) \text {, OP-20 X S }}_{3}\left(2.43 \mathrm{mg} 100 \mathrm{~g}^{-1}\right)\right.$.

The data furnished in Table 2 revealed that flavonoid content recorded was maximum at site $S_{3}$ might be due to vehicular pollution resulted in significant increase in the total flavonoid content of Peltophorum pterocarpum (OP-4) plants at site $\mathrm{S}_{3}$ (Railway Kodur). A similar trend was reported with the findings of ${ }^{[11]}$, who have reported increase in total flavonoids in Artemisia vulgaris L. and Veronica chamaedrys L. in relation to air pollution stress. Total flavonoids in plants increased by increasing pollution loads across the sites, hence, this validates their role as biomarkers of auto exhaust pollution ${ }^{[12]}$. The increase in the total flavonoid content may also be attributed to other environmental pollution.

\section{Phenol content}

Phenol content varied significantly due to the influence of ornamental plants, locations and their interactions. Among the ornamental plants, OP-4 noticed to have the highest phenol content (25.34 mg $100 \mathrm{~g}^{-1}$ ) which was found significantly superior to other ornamental plants followed by OP-3 (19.84 mg $\left.100 \mathrm{~g}^{-1}\right)$, OP-7 (11.48 mg $\left.100 \mathrm{~g}^{-1}\right)$, OP-5 (9.02 mg $\left.100 \mathrm{~g}^{-1}\right)$ and OP-8 (8.73 mg $\left.100 \mathrm{~g}^{-1}\right)$. Among sites, $\mathrm{S}_{3}$ found significantly superior in having phenol content $(6.87 \mathrm{mg} 100$ $\left.\mathrm{g}^{-1}\right)$ followed by $\mathrm{S}_{2}\left(6.11 \mathrm{mg} 100 \mathrm{~g}^{-1}\right), \mathrm{S}_{4}\left(5.70 \mathrm{mg} 100 \mathrm{~g}^{-1}\right)$ and $S_{1}\left(5.22 \mathrm{mg} 100 \mathrm{~g}^{-1}\right)$. In interaction, the combination of OP-4 X S 3 had significantly highest phenol content $(26.08 \mathrm{mg}$ $\left.100 \mathrm{~g}^{-1}\right)$ which was on par with OP-4X S $2\left(25.49 \mathrm{mg} 100 \mathrm{~g}^{-1}\right)$. Phenols act as a free radical scavengers to protect plants away from damage by oxidative stress. They play important role in maintaining cellular osmotic potential when plant is exposed to stress conditions especially air pollution. The highest concentration of total phenols in the leaves of Peltophorum pterocarpum (OP-4) may be attributed to its genetic constitution and moreover, due to its highest tolerance to the pollution as an adaptation to avoid the adverse effect of air pollution at $S_{3}$ (Railway Kodur). The increase in the concentration of total phenols in the plants growing at $S_{3}$ may be ascribed to higher pollution load near to the location particularly with vehicles and other pollutants. The results are in agreement with the findings of ${ }^{[13-14]}$ who studied the increase in phenolic compounds in plants exposed to various pollutants.

\section{Proline content}

The data furnished in Table 2 revealed that proline content varied significantly by ornamental plants, study sites and their interactions. The results demonstrate that the ornamental plant OP-3 recorded maximum proline content $\left(158.76 \mu \mathrm{g} \mathrm{g}^{-1}\right)$ followed by OP-1 (153.81 $\left.\mathrm{g} \mathrm{g}^{-1}\right)$, OP-4 (101.97 $\left.\mu \mathrm{g} \mathrm{g}^{-1}\right)$, OP$11\left(87.68 \mu \mathrm{g} \mathrm{g}^{-1}\right)$ and OP-5 $\left(81.53 \mu \mathrm{g} \mathrm{g}^{-1}\right)$. Among the sites, $\mathrm{S}_{3}$ showed maximum value $\left(37.94 \mu \mathrm{g} \mathrm{g}^{-1}\right)$ followed by $\mathrm{S}_{2}(34.21$ $\left.\mu \mathrm{g} \mathrm{g}{ }^{-1}\right)$ and $\mathrm{S}_{4}\left(32.86 \mu \mathrm{g} \mathrm{g} \mathrm{g}^{-1}\right)$. Combination of ornamental plants and sites interaction showed maximum proline in OP-3 $\mathrm{X} \mathrm{S}_{3}\left(183.00 \mu \mathrm{g} \mathrm{g}^{-1}\right)$ which differed significantly among all interactions.

Among the ornamental plant species tried at multiple sites, Delonix regia (OP-3) had highest proline content at site $\mathrm{S}_{3}$ 
(Railway Kodur-highly polluted area). ${ }^{[15]}$ also observed a higher proline content in plant leaf in pollution stress sites. Proline acts as an absorbent and free radical to protect plants against oxidative stress. High proline content helps in osmotic adjustment of a plant cells under pollution stress. The present work also demonstrated that under air pollution conditions at $\mathrm{S}_{3}$, proline level of polluted leaves increased significantly. Because when the physiological stress of plant increases, then the secretion of proline also increases and the secretion of proline in stress conditions is a plant natural physiological process ${ }^{[15]}$.

\section{Peroxidase activity}

Data recorded on peroxidase was significantly influenced by different ornamental plants and study sites during sampling season (Table 3). Results revealed that, the ornamental plant OP-13 had highest peroxidase activity (87.99 $\Delta \mathrm{OD} \mathrm{min}^{-1} \mathrm{~g}^{-1}$ FW) which was followed by OP-2 (73.30 $\Delta$ OD $\left.\mathrm{min}^{-1} \mathrm{~g}^{-1} \mathrm{FW}\right)$, OP-9 (66.16 $\Delta$ OD min $\left.{ }^{-1} \mathrm{~g}^{-1} \mathrm{FW}\right)$, OP-22 (63.40 $\Delta$ OD min ${ }^{-1} \mathrm{~g}^{-1}$ $\mathrm{FW})$ and OP-21 (56.42 $\left.\Delta \mathrm{OD} \mathrm{min}^{-1} \mathrm{~g}^{-1} \mathrm{FW}\right)$. Among the sites, $\mathrm{S}_{3}$ site had maximum peroxidase $\left(28.74 \Delta \mathrm{OD} \min ^{-1} \mathrm{~g}^{-1} \mathrm{FW}\right)$ followed by $\mathrm{S}_{2}\left(28.00 \Delta \mathrm{OD} \mathrm{min}^{-1} \mathrm{~g}^{-1} \mathrm{FW}\right), \mathrm{S}_{4}(27.16 \Delta \mathrm{OD}$ $\min ^{-1} \mathrm{~g}^{-1} \mathrm{FW}$ ). None of the interaction of ornamental plants $\mathrm{X}$ sites responded significantly with respect to peroxidase. The results demonstrate that peroxidase activity recorded was highest in Hibiscus rosa-sinensis (OP-13) at site $\mathrm{S}_{3}$. The results obtained find support from ${ }^{[16]}$, they reported that an increase in peroxidase activity in plants under a variety of stresses like mechanical injury and attack by pathogens or an influence of environmental pollution. The increase in peroxidase activity varies with the plant species and the concentration of pollutants. It has been reported that leaves of the resistant plants might have high peroxidase activity ${ }^{[17]}$. Peroxidase activities in all the species were found to be maximum at severe air pollution site $\left(S_{2}\right.$ and $\left.S_{3}\right)$ than other sites $\left(S_{1}\right)$. This may be due to the more interlinked primary protection mechanism offered by peroxidase in plants to protect themselves at severe air pollution site as compared to the less polluted sites. Inherent genetic set up of the species is found to be another reason for the above result. Similarly, in a study by ${ }^{[18]}$ shown that in response to air pollution, the activity of peroxidase from Prosopis juliflora leaves has increased. Several researches have suggested that peroxidase activity may not be used as a specific indicator of single air pollutant and can only be considered as a general indicator of oxidative stress ${ }^{[19]}$.

\section{Catalase activity}

The data in Table 3 revealed that the catalase in the leaves of selected plants was found to vary among the ornamental plants growing at different sites. Results showed that ornamental plant i.e. OP-15 recorded highest catalase activity
(63.48 $\mu \mathrm{mol} \mathrm{H}_{2} \mathrm{O}_{2} \mathrm{~min}^{-1} \mathrm{~g}^{-1} \mathrm{FW}$ ) which was followed by OP19 (51.39 $\left.\mu \mathrm{mol} \mathrm{H} \mathrm{O}_{2} \mathrm{~min}^{-1} \mathrm{~g}^{-1} \mathrm{FW}\right), \mathrm{OP}-16\left(47.54 \mu \mathrm{mol} \mathrm{H}_{2} \mathrm{O}_{2}\right.$ $\left.\min ^{-1} \mathrm{~g}^{-1} \mathrm{FW}\right)$, OP-11 (44.34 $\left.\mu \mathrm{mol} \mathrm{H}_{2} \mathrm{O}_{2} \min ^{-1} \mathrm{~g}^{-1} \mathrm{FW}\right)$ and OP-20 (42.53 $\mu$ mol $\mathrm{H}_{2} \mathrm{O}_{2}$ min $\left.^{-1} \mathrm{~g}^{-1} \mathrm{FW}\right)$. Among the sites, $\mathrm{S}_{3}$ site recorded maximum catalase $\left(27.98 \mu \mathrm{mol} \mathrm{H} \mathrm{H}_{2} \mathrm{O}_{2} \mathrm{mi}^{-1} \mathrm{~g}^{-1}\right.$ FW) followed by $\mathrm{S}_{2}\left(26.91 \mu \mathrm{mol} \mathrm{H}_{2} \mathrm{O}_{2} \mathrm{~min}^{-1} \mathrm{~g}^{-1} \mathrm{FW}\right), \mathrm{S}_{4}$ (26.19 $\mu \mathrm{mol} \mathrm{H} \mathrm{H}_{2} \mathrm{~min}^{-1} \mathrm{~g}^{-1} \mathrm{FW}$ ). The interaction of plants $\mathrm{X}$ sites was not having significant influence with respect to catalase.

The average activity of catalase enzyme was increased in all of the species at the site $\mathrm{S}_{3}$ particularly in Tecoma stans (OP15) may be due to the genetic inherent characters of the genotype and climatic diversity. An efficient anti-oxidative defense system with antioxidative enzymes like catalase are present in plants to counteract oxidative stress ${ }^{[20]}$. In plants, catalase is one of the main $\mathrm{H}_{2} \mathrm{O}_{2}$-scavenging enzyme, detoxify $\mathrm{H}_{2} \mathrm{O}_{2}$ and dismutates $\mathrm{H}_{2} \mathrm{O}_{2}$ into water and $\mathrm{O}_{2}$, and it is a constitutive component of peroxisomes and protect themselves against oxidative stress. The results of current experiment exhibited that the plants grown in high polluted site $\left(\mathrm{S}_{3}\right)$ showed changes in catalase activity in comparison to control site $\left(\mathrm{S}_{1}\right)$. Our results are in agreement with the findings by ${ }^{[18-20]}$.

\section{Malondialdehyde content (MDA)}

A significant variation was noticed in the Malondialdehyde (MDA) content among ornamental plant species and study sites (Table 3). Among the ornamental plants investigated, OP-15 exhibited the highest MDA content (3.66 nmol MDA $\left.\mathrm{g}^{-1}\right)$ which was found significantly superior to other ornamental plants and followed by OP-8 (2.85 nmol MDA g $\mathrm{g}^{-}$ $\left.{ }^{1}\right)$. The response of MDA content among selected sites was significant. Maximum value was recorded at $S_{3}(2.02 \mathrm{nmol}$ MDA g $\left.{ }^{-1}\right)$ followed by $S_{2}\left(1.72 \mathrm{nmol} \mathrm{MDA} \mathrm{g}{ }^{-1}\right), S_{4}(1.14 \mathrm{nmol}$ MDA $\left.\mathrm{g}^{-1}\right)$ and $\mathrm{S}_{1}\left(0.98 \mathrm{nmol} \mathrm{MDA} \mathrm{g}^{-1}\right)$. It was observed that no significant response was noticed with the influence of ornamental plants X sites on MDA.

A perusal of the data depicted that among ornamental plants, Tecoma stans (OP-15) grown at high polluted area $\left(\mathrm{S}_{3}\right)$ registered maximum value for the above trait. Malondialdehyde (MDA) is a major cytotoxic product of lipid peroxidation and acts as indicator of free radical production and therefore, formation of MDA is considered as measure of lipid peroxidation. The role of redox metals in the onset of peroxidation of membrane lipids in the plants have been realized due to induction of toxic oxygen species. The formation of malondialdehyde (MDA) was considered as a measure of lipid peroxidation ${ }^{[21]}$. There are various reports ${ }^{[22-}$ 23] which conferred similar conclusions showing an increase in the level of MDA content in the plants grown on treated tannery sludge amendments due to the presence of redox metals.

Table 2: Response of ornamental plants (OP), sites (S) and their interaction to various pollutants in respect of flavonoid, phenol and proline

\begin{tabular}{|c|c|c|c|c|c|c|c|c|c|c|c|c|c|c|c|}
\hline \multirow{2}{*}{ Ornamental plant } & \multicolumn{5}{|c|}{ Flavonoid content } & \multicolumn{5}{|c|}{ Phenol content } & \multicolumn{5}{|c|}{ Proline } \\
\hline & $\mathbf{S}_{1}$ & $\mathbf{S}_{\mathbf{2}}$ & $\mathbf{S}_{\mathbf{3}}$ & $\mathbf{S}_{\mathbf{4}}$ & Mean & $\mathbf{S}_{1}$ & $\mathbf{S}_{\mathbf{2}}$ & $\mathbf{S}_{3}$ & $\mathbf{S}_{4}$ & Mean & $\mathbf{S}_{1}$ & $\mathbf{S}_{2}$ & $\mathbf{S}_{3}$ & $\mathbf{S}_{4}$ & Mean \\
\hline OP-1 & 0.95 & 2.16 & 2.50 & 1.81 & 1.86 & 5.67 & 6.84 & 7.43 & 6.26 & 6.55 & 134.44 & 158.46 & 168.01 & 154.34 & 153.81 \\
\hline OP-2 & 0.06 & 0.13 & 0.48 & 0.09 & 0.19 & 6.42 & 7.45 & 8.04 & 6.86 & 7.19 & 9.34 & 17.87 & 20.72 & 17.34 & 16.32 \\
\hline OP-3 & 0.03 & 0.14 & 0.48 & 0.07 & 0.18 & 19.28 & 20.02 & 20.61 & 19.44 & 19.84 & 117.34 & 170.77 & 183.00 & 163.93 & 158.76 \\
\hline OP-4 & 1.37 & 1.92 & 2.26 & 1.77 & 1.83 & 24.87 & 25.49 & 26.08 & 24.90 & 25.34 & 83.43 & 102.32 & 120.87 & 101.24 & 101.97 \\
\hline OP-5 & 0.90 & \begin{tabular}{|l|}
1.68 \\
\end{tabular} & 2.02 & 1.31 & 1.48 & 8.28 & 9.27 & 9.86 & 8.68 & 9.02 & 50.98 & 89.40 & 97.57 & 88.16 & 81.53 \\
\hline OP-6 & 1.21 & \begin{tabular}{|l|}
1.97 \\
\end{tabular} & 2.31 & 1.54 & 1.76 & 2.79 & 3.90 & 4.49 & 3.31 & 3.62 & 8.16 & 16.89 & 18.63 & 15.87 & 14.89 \\
\hline OP-7 & 0.53 & 1.58 & 1.93 & 0.88 & 1.23 & 10.78 & 11.71 & 12.30 & 11.13 & 11.48 & 1.17 & 4.62 & 7.68 & 4.19 & 4.42 \\
\hline OP-8 & 0.12 & \begin{tabular}{|l|}
0.21 \\
\end{tabular} & 0.56 & 0.17 & 0.27 & 7.98 & 8.98 & 9.56 & 8.39 & 8.73 & 1.31 & 4.08 & 6.81 & 2.89 & 3.77 \\
\hline OP-9 & 0.35 & 0.94 & 1.29 & 0.67 & 0.81 & 1.83 & 2.96 & 3.55 & 2.38 & 2.68 & 3.15 & 11.70 & 14.30 & 10.73 & 9.97 \\
\hline
\end{tabular}




\begin{tabular}{|c|c|c|c|c|c|c|c|c|c|c|c|c|c|c|c|}
\hline OP-10 & \begin{tabular}{|l|}
0.59 \\
\end{tabular} & \begin{tabular}{|l|l|}
1.69 \\
\end{tabular} & 2.03 & \begin{tabular}{|l|}
0.85 \\
\end{tabular} & 1.29 & 4.78 & 5.85 & 6.43 & 5.26 & 5.58 & 0.85 & 1.37 & 1.93 & 1.07 & 1.30 \\
\hline OP-11 & \begin{tabular}{|c|}
0.08 \\
\end{tabular} & 0.21 & 0.55 & \begin{tabular}{|l|}
0.14 \\
\end{tabular} & 0.25 & 1.68 & 2.82 & 3.40 & 2.23 & 2.53 & 73.79 & 92.54 & 95.96 & 88.41 & 87.68 \\
\hline OP-12 & 0.90 & 1.77 & 2.11 & 1.41 & 1.55 & 1.68 & 2.82 & 3.40 & 2.23 & 2.53 & 6.32 & 13.77 & 15.04 & 13.54 & 12.17 \\
\hline OP-13 & \begin{tabular}{l|l|}
0.09 \\
\end{tabular} & \begin{tabular}{|l|}
0.18 \\
\end{tabular} & 0.52 & \begin{tabular}{|l|}
0.13 \\
\end{tabular} & 0.23 & 1.70 & 2.84 & 3.42 & 2.25 & 2.55 & 1.59 & 5.41 & 7.25 & 4.44 & 4.67 \\
\hline OP-14 & 0.16 & 0.33 & 0.68 & 0.26 & 0.36 & 2.13 & 3.26 & 3.84 & 2.67 & 2.98 & 2.20 & 5.81 & 7.76 & 5.29 & 5.27 \\
\hline OP-15 & 0.95 & \begin{tabular}{|l|l}
1.97 \\
\end{tabular} & 2.31 & 1.29 & 1.63 & 2.56 & 3.68 & 4.26 & 3.09 & 3.40 & 43.39 & 63.42 & 68.71 & 62.32 & 59.46 \\
\hline OP-16 & 0.63 & 2.14 & 2.48 & 1.69 & 1.74 & 3.17 & 4.27 & 4.86 & 3.69 & 4.00 & 1.94 & 12.75 & 14.72 & 11.62 & 10.26 \\
\hline OP-17 & \begin{tabular}{l|l}
0.18 \\
\end{tabular} & \begin{tabular}{|l|l|}
0.77 \\
\end{tabular} & 1.11 & 0.34 & 0.60 & 1.98 & 3.11 & 3.70 & 2.52 & 2.83 & 0.74 & 1.80 & 3.11 & 1.05 & 1.68 \\
\hline OP-18 & 0.14 & 0.45 & 0.79 & 0.33 & 0.43 & 1.37 & 2.51 & 3.10 & 1.93 & 2.23 & 1.18 & 2.78 & 3.67 & 2.08 & 2.43 \\
\hline OP-19 & \begin{tabular}{|l|}
0.11 \\
\end{tabular} & \begin{tabular}{|l|l|}
0.63 \\
\end{tabular} & 0.97 & 0.36 & 0.52 & 2.63 & 3.74 & 4.33 & 3.16 & 3.47 & 3.78 & 17.08 & 19.09 & 16.39 & 14.09 \\
\hline OP-20 & 1.16 & 2.09 & 2.43 & 1.62 & 1.83 & 2.98 & 4.09 & 4.67 & 3.50 & 3.81 & 1.39 & 2.47 & 4.58 & 1.51 & 2.49 \\
\hline OP-21 & 0.14 & \begin{tabular}{|l|}
0.82 \\
\end{tabular} & 1.16 & 0.19 & 0.58 & 3.16 & 4.26 & 4.85 & 3.68 & 3.99 & 4.65 & 17.25 & 18.67 & 16.63 & 14.30 \\
\hline OP-22 & \begin{tabular}{|l|l}
0.10 \\
\end{tabular} & \begin{tabular}{|l|}
0.80 \\
\end{tabular} & 1.14 & 0.17 & 0.55 & 2.89 & 4.00 & 4.59 & 3.41 & 3.72 & 0.56 & 3.01 & 3.67 & 2.18 & 2.35 \\
\hline OP-23 & 0.44 & \begin{tabular}{|l|}
1.81 \\
\end{tabular} & 2.15 & 1.02 & 1.36 & 2.48 & 3.60 & 4.18 & 3.01 & 3.32 & 0.72 & 2.08 & 3.09 & 1.19 & 1.77 \\
\hline OP-24 & 0.17 & $\mid 0.77$ & 1.11 & 0.45 & 0.63 & 2.17 & 3.30 & 3.88 & 2.71 & 3.02 & 0.87 & 3.43 & 5.84 & 2.28 & 3.10 \\
\hline Mean & \begin{tabular}{|l|}
0.47 \\
\end{tabular} & \begin{tabular}{|l}
1.13 \\
\end{tabular} & 1.47 & 0.77 & & 5.22 & 6.28 & 6.87 & 5.70 & & 23.06 & 34.21 & 37.94 & 32.86 & \\
\hline & OP & \begin{tabular}{|l|} 
\\
\end{tabular} & $\mathrm{OP} \times \mathrm{S}$ & & & $\mathrm{OP}$ & $\mathrm{S}$ & $\mathrm{OP} \times \mathrm{S}$ & & & $\mathrm{OP}$ & $\mathrm{S}$ & $\mathrm{OP} \times \mathrm{S}$ & & \\
\hline $\mathrm{CD}[P=0.05]$ & 0.04 & 0.02 & 0.09 & & & 0.35 & 0.14 & NS & & & 2.39 & 0.97 & 4.78 & & \\
\hline
\end{tabular}

Table 3: Response of ornamental plants (OP), sites (S) and their interaction to various pollutants in respect of peroxidase, catalase and MDA

\begin{tabular}{|c|c|c|c|c|c|c|c|c|c|c|c|c|c|c|c|}
\hline \multirow{2}{*}{ Ornamental plant } & \multicolumn{5}{|c|}{ Peroxidase activity } & \multicolumn{5}{|c|}{ Catalase activity } & \multicolumn{5}{|c|}{ MDA content } \\
\hline & $\mathbf{S}_{1}$ & \begin{tabular}{|l|}
$\mathbf{S}_{2}$ \\
\end{tabular} & $\mathbf{S}_{3}$ & $\mathrm{~S}_{4}$ & Mean & $\mathbf{S}_{1}$ & \begin{tabular}{|l|}
$\mathbf{S}_{2}$ \\
\end{tabular} & \begin{tabular}{l|}
$\mathbf{S}_{3}$ \\
\end{tabular} & $\mathrm{~S}_{4}$ & Mean & $\mathbf{S}_{1}$ & $\mathbf{S}_{\mathbf{2}}$ & $\mathbf{S}_{\mathbf{3}}$ & $\mathbf{S}_{4}$ & Mean \\
\hline OP-1 & 50.91 & 52.60 & 53.35 & 51.69 & 52.14 & 20.65 & 22.50 & 23.68 & 21.72 & 22.14 & 1.33 & 2.07 & 2.37 & 1.49 & 1.82 \\
\hline OP-2 & 72.09 & 73.73 & 74.53 & 72.87 & 73.30 & 11.70 & 13.56 & 14.74 & 12.78 & 13.20 & 1.15 & 1.89 & 2.19 & 1.31 & 1.63 \\
\hline OP-3 & 0.96 & 1.43 & 1.73 & 1.10 & 1.30 & 37.75 & 39.61 & 40.78 & 38.83 & 39.24 & 0.14 & 0.88 & 1.17 & 0.29 & 0.62 \\
\hline OP-4 & 1.10 & 2.63 & 3.42 & 1.75 & 2.22 & 29.81 & 31.67 & 32.84 & 30.89 & 31.30 & 0.33 & 1.07 & 1.36 & 0.48 & 0.81 \\
\hline OP-5 & 1.21 & 2.63 & 3.42 & 1.75 & 2.25 & 13.97 & 15.83 & 17.00 & 15.05 & 15.46 & 1.16 & 1.91 & 2.20 & 1.32 & 1.65 \\
\hline OP-6 & 18.46 & 20.13 & 20.91 & 19.25 & 19.69 & 25.74 & 27.59 & 28.77 & 26.82 & 27.23 & 0.96 & \begin{tabular}{|l|}
1.71 \\
\end{tabular} & 2.00 & 1.12 & 1.45 \\
\hline OP-7 & 0.87 & 2.27 & 3.05 & 1.39 & 1.89 & 24.15 & 26.00 & 27.18 & 25.22 & 25.64 & 0.67 & 1.42 & 1.71 & 0.83 & 1.16 \\
\hline OP-8 & 53.26 & 54.90 & 55.71 & 54.05 & 54.48 & 10.49 & 12.34 & 13.51 & 11.56 & 11.98 & 2.37 & 3.11 & 3.41 & 2.53 & 2.85 \\
\hline OP-9 & 64.94 & 66.60 & 67.38 & 65.72 & 66.16 & 16.14 & 18.00 & 19.17 & 17.21 & 17.63 & 0.92 & 1.67 & 1.96 & 1.08 & 1.41 \\
\hline OP-10 & 3.49 & 5.13 & 5.94 & 4.28 & 4.71 & 33.40 & 35.26 & 36.43 & 34.48 & 34.89 & 1.72 & 2.47 & 2.76 & 1.88 & 2.21 \\
\hline OP-11 & 22.39 & 24.07 & 24.83 & 23.16 & 23.61 & 42.85 & 44.70 & 45.88 & 43.92 & 44.34 & 0.72 & \begin{tabular}{|l|}
1.47 \\
\end{tabular} & 1.76 & 0.88 & 1.21 \\
\hline OP-12 & 42.39 & 44.07 & 44.83 & 43.17 & 43.62 & 3.15 & 4.01 & 4.53 & 3.70 & 3.85 & 0.74 & 1.48 & 1.77 & 0.89 & 1.22 \\
\hline OP-13 & 86.76 & 88.43 & 89.21 & 87.55 & 87.99 & 20.83 & 22.68 & 23.85 & 21.90 & 22.31 & 1.37 & 2.12 & 2.41 & 1.53 & 1.86 \\
\hline OP-14 & 18.25 & 19.90 & 20.70 & 19.04 & 19.47 & 3.05 & 3.80 & 4.03 & 3.38 & 3.57 & 0.29 & 1.03 & 1.33 & 0.45 & 0.78 \\
\hline OP-15 & 18.32 & 20.00 & 20.77 & 19.11 & 19.55 & 61.99 & 63.84 & 65.02 & 63.06 & 63.48 & 3.18 & 3.92 & 4.22 & 3.34 & 3.66 \\
\hline OP-16 & 1.52 & 3.17 & 3.97 & 2.30 & 2.74 & 46.05 & 47.91 & 49.08 & 47.12 & 47.54 & 1.72 & 2.47 & 2.76 & 1.88 & 2.21 \\
\hline OP-17 & 11.26 & 12.93 & 13.70 & 12.04 & 12.49 & 1.41 & 1.92 & 2.43 & 1.94 & 1.92 & 0.08 & 0.83 & 1.12 & 0.24 & 0.57 \\
\hline OP-18 & 1.13 & 2.83 & 3.58 & 1.92 & 2.37 & 15.11 & 16.97 & 18.14 & 16.18 & 16.60 & 0.46 & $\begin{array}{l}1.20 \\
\end{array}$ & 1.50 & 0.62 & 0.95 \\
\hline OP-19 & 0.87 & 1.90 & 2.23 & 1.20 & 1.55 & 49.90 & 51.76 & 52.93 & 50.97 & 51.39 & 0.16 & 0.91 & 1.20 & 0.32 & 0.65 \\
\hline OP-20 & 41.97 & 43.60 & 44.41 & 42.75 & 43.18 & 41.04 & 42.90 & 44.07 & 42.12 & 42.53 & 0.85 & 1.60 & 1.89 & 1.01 & 1.34 \\
\hline OP-21 & 55.20 & 56.87 & 57.65 & 55.98 & 56.42 & 26.70 & 28.56 & 29.73 & 27.77 & 28.19 & 1.07 & 1.81 & 2.10 & 1.22 & 1.55 \\
\hline OP-22 & 62.19 & 63.83 & 64.63 & 62.96 & 63.40 & 10.88 & 12.74 & 13.92 & 11.96 & 12.38 & 0.02 & 0.77 & 1.06 & 0.18 & 0.51 \\
\hline OP-23 & 5.02 & 6.70 & 7.46 & 5.80 & 6.25 & 29.66 & 31.52 & 32.69 & 30.73 & 31.15 & 1.46 & 2.20 & 2.50 & 1.62 & 1.94 \\
\hline OP-24 & 0.66 & 1.60 & 2.40 & 1.11 & 1.44 & 28.20 & 30.06 & 31.23 & 29.28 & 29.69 & 0.58 & 1.32 & 1.61 & 0.73 & 1.06 \\
\hline Mean & 26.47 & 28.00 & 28.74 & 27.16 & & 25.19 & 26.91 & 27.98 & 26.19 & & 0.98 & 1.72 & 2.02 & 1.14 & \\
\hline \multirow[b]{2}{*}{$\mathrm{CD}[P=0.05]$} & $\mathrm{OP}$ & $\mathrm{S}$ & $\mathrm{OP} \times \mathrm{S}$ & & & $\mathrm{OP}$ & $\mathrm{S}$ & OPxS & & & OP & $\mathrm{S}$ & $\mathrm{OP} \times \mathrm{S}$ & & \\
\hline & 1.58 & 0.64 & NS & & & 1.24 & 0.50 & NS & & 72.16 & 0.06 & 0.02 & NS & & \\
\hline
\end{tabular}

\section{References}

1. Badamasi H. Biomonitoring of air pollution using plants. J Environ. Sci 2017;2:27-39.

2. Akilan M, Nandhakumar S. Air pollution tolerance index of selected plants in industrial and urban areas of Vellore district. Agri Sci Digest 2016;36(1):66-68.

3. Tsega YC, Deviprasad AG. Variation in air pollution tolerance index and anticipated performance index of roadside plants in Mysore, India. J Environ. Biology 2014;35:185-190.

4. Kaur M, Nagpal AK. Evaluation of Air Pollution Tolerance Index and Anticipated Performance Index of plants and their application in development of green space along the urban areas. Environ Science and Pollu Res 2017;24:18881-18895.
5. Chun OK, Kim D, Lee CY. Superoxide radical scavenging activity of the major polyphenols in fresh plums. J Agri Food Chem 2003;51(27):8067-8072.

6. Singleton VI, Joseph A, Rossi. Colorimetry of total phenolics with phosphomolybdic- phosphotungstic acid reagents. American $\mathrm{J}$ Enology and Viticulture 1965;16:144-158.

7. Bates IS, Waldren RP, Tarc ID. Rapid determination of free proline for water stress studies. Plant Soil 1973;39:205-207.

8. Sadasivam S, Manickam A. Biochemical method for agricultural sciences 1992,12-13.

9. Aebi H. Catalase in vitro. Methods in Enzymology 1984;105:121-126.

10. Heath RL, Packer L. Photoperoxidation in isolated chloroplast I. kinetics and stoichiometry of fatty acid 
peroxidation. Archives of Biochem and Biophy 1968;125:189-198.

11. Nikolova MT, Ivancheva SV. Quantitative flavonoid variations of Artemisia vulgaris L. and Veronica chamaedrys L. in relation to altitude and polluted environment. Acta Biologica 2005;49(34):29-32.

12. Mir QA, Yazdani T, Ahmad S, Yunus M. Total flavonoids and phenolics in Catharanthusroseus $L$. and Ocimum sanctum $L$. as biomarkers of urban auto pollution. Caspian J Environ Sciences 2009;7(1):9-16.

13. Chandawat DK, Verma PU, Solanki HA, Patel YM. Role of total phenol in the resistance mechanism of plants against air pollution. Biolife 2014;2(2):586-592.

14. Mohsenpour P, Amjad L, Yahyaabadi S. The effect of environmental pollutions on phytochemical parameters and antioxidant activity of Quince, Apple, and Mulberry fruits. J Biodiversity and Environ Sciences. 2015;6(1):282-289.

15. Seyyednejad SM, Koochak H. A study on air pollution effects on Eucalyptus camaldulensis in international conference on environmental, biomedical, and biotechnology. Singapore: IACSIT 2011;16:98-101.

16. Varshney SRK, Varshney CK. Response of peroxidase to low levels of $\mathrm{SO}_{2}$. Environ and Experimental Bot 1985;25:107-114.

17. Tripathi AK, Gautam M. Biochemical parameters of plants as indicators of air pollution. J of Environ Biology 2007;28:127-132.

18. Seyyednejad SM, Koochak H, Vaezi J. Changes in antioxidative enzymes activity, protein content and ascorbic acid level in Prosopis juliflora exposed to industrial air pollution. J of Biol and Today's World 2013;2(10):482492.

19. Li MH. Peroxidase and superoxide dismutase activities in fig leaves in response to ambient air pollution in a subtropical city. Archives of Environ Contamination and Toxicology 2003;45:168-176.

20. Rai PK. Biodiversity of roadside plants and their response to air pollution in an Indo-Burma hotspot region: implications for urban ecosystem restoration. J Asia-Pacific Biodiversity 2016;9:47-55.

21. Halliwell B, Gutteridge JMC. Free radicals in biology and medicine. Clarendron Press, Oxford 2004.

22. Sinha S, Saxena R, Singh S. Chromium induced lipid peroxidation and its effect on antioxidants and antioxidant enzymes of Pistia stratiotes L. Chemosphere 2005;58:595-604.

23. Sinha S, Saxena R. Effect of iron on lipid peroxidation, and enzymatic and non-enzymatic antioxidants and bacoside - a content in medicinal plant Bacopa monnieri L. Chemosphere 2006;62:1340-1350. 